\title{
Disentangling trade-offs and synergies around ecosystem services with the influence network framework: illustration from a consultative process over the French Alps
}

\author{
$\underline{\text { Emilie Crouzat }}^{1}$, Berta Martín-López $^{2}$, Francis Turkelboom $^{3}$ and $^{\text {Sandra Lavorel }}{ }^{1}$
}

\begin{abstract}
An important aspect of sustainability is to maintain biodiversity and ecosystem functioning while improving human well-being. For this, the ecosystem service (ES) approach has the potential to bridge the still existing gap between ecological management and social development, especially by focusing on trade-offs and synergies between ES and between their beneficiaries. Several frameworks have been proposed to account for trade-offs and synergies between ES, and between ES and other components of socialecological systems. However, to date, insufficient explicit attention has been paid to the three facets encompassed in the ES concept, namely potential supply, demand, and use, leading to incomplete descriptions of ES interactions. We expand on previous frameworks by proposing a new influence network framework (INF) based on an explicit consideration of influence relationships between these three ES facets, biodiversity, and external driving variables. We tested its ability to provide a comprehensive view of complex socialecological interactions around ES through a consultative process focused on environmental management in the French Alps. We synthetized the interactions mentioned during this consultative process and grouped variables according to their overall propensity to influence or be influenced by the system. The resulting directed sequence of influences distinguished between: (1) mostly influential variables (dynamic social variables and ecological state variables), (2) target variables (provisioning and cultural services), and (3) mostly impacted variables (regulating services and biodiversity parameters). We discussed possible reasons for the discrepancies between actual and perceived influences and proposed options to overcome them. We demonstrated that the INF holds the potential to deliver collective assessments of ES relations by: (1) including ecological as well as social aspects, (2) providing opportunities for colearning processes between stakeholder groups, and (3) supporting communication about complex social-ecological systems and consequences for environmental management.
\end{abstract}

Key Words: cross-sectoral stakeholder consultation; ecosystem service potential supply, demand, and use; French Alps; influence networks; trade-offs and synergies

\section{INTRODUCTION}

The ecosystem service (ES) concept aims to bridge the still existing gap between ecological management and social development (Chan et al. 2012, Reyers et al. 2013, Martín-López et al. 2014). In particular, addressing ES trade-offs and synergies, respectively, consistent negative and positive covariations (Mouchet et al. 2014), could support more sustainable management of environmental resources, required both for maintaining desired ecosystem functioning and enhancing human well-being (Rodríguez et al. 2006, Kareiva et al. 2007, Luck et al. 2012).

At the interface between social and ecological systems (MEA 2005), ES integrate biophysical and socio-cultural factors (Bennett et al. 2009, Reyers et al. 2013). To characterize their pivotal function, authors have itemized the different facets constitutive of individual ES with the motivation that their joint consideration could support a more integrative approach of the multiple relationships between ES and social-ecological systems (Burkhard et al. 2012, Villamagna et al. 2013, Bagstad et al. 2014, Geijzendorffer et al. 2015). Given current lack of consensus on terminology, reviewed by Villamagna et al. (2013) and Geijzendorffer et al. (2015)), the three facets will be hereafter referred to as ES potential supply, demand, and use. First, potential supply is defined as the ecosystem biophysical capacity to supply services (Bastian et al. 2012), because of the combination of geophysical and ecological characteristics under current land use. It has been also referred to as "capacity" (Villamagna et al. 2013, Schröter et al. 2014) or "managed supply" (Geijzendorffer et al. 2015). Second, demand is understood as the "social demand for using a particular ES in a specific area" (García-Nieto et al. 2013:126) and represents "the amount of service desire by society" (Villamagna et al. 2013:115). Demand arises from individual and social preferences (Wolff et al. 2015) and includes the "effort people are willing to invest" to benefit from the ES (Geijzendorffer et al. 2015), e.g., in terms of time, money, or travelling distance. Third, use depicts the actual encounter of demand and potential supply. It relates to the capacity of ecosystems to fulfil social demands and has also been called "budget" (Burkhard et al. 2012), "flow" (Villamagna et al. 2013, Schröter et al. 2014) or "match" (Geijzendorffer et al. 2015). Use incorporates the influence of social arrangements and regulations, such as policy constraints and power balances. These three facets equally apply to provisioning, cultural, and regulating ES.

Contemporary to this formalization, extensive research has also focused on framing ES trade-offs and synergies. Among proposed conceptual models, Bennett et al. (2009) suggested distinguishing

${ }^{1}$ Laboratoire d'Ecologie Alpine, CNRS, Université Grenoble Alpes, France, ${ }^{2}$ Leuphana University of Lüneburg, Faculty of Sustainability, Institute of Ethics and Transdisciplinary Sustainability Research, Germany, ${ }^{3}$ Research Group Nature and Society, Research Institute for Nature and Forest (INBO), Belgium 
direct relations between pairs of ES from indirect relations linked to external factors. As a complementary approach, Kandziora et al. (2013) described main supporting, reducing, and feedback links between pairs of ES using direct interrelation matrices.

To date, many studies have addressed ES trade-offs and synergies from the perspective of their potential supply (e.g., Anderson et al. 2009, Raudsepp-Hearne et al. 2010, Bai et al. 2011), to provide a better ecological understanding required for robust management decisions (Kremen 2005). Furthermore, acknowledging the necessity of taking into account social components, some have integrated demand into trade-off assessments for a single ES, e.g., pollination (Schulp et al. 2014), or for multiple ES (García-Nieto et al. 2013, Hauck et al. 2013, Palomo et al. 2013). Finally, ES use of facets has been considered to characterize the (mis)matches between supply and demand (Bagstad et al. 2014, Van der Biest et al. 2014). However, although ES facets are part of the many criteria proposed to characterize and classify trade-offs and synergies between ES (Mouchet et al. 2014, Van der Biest et al. 2014), most assessments have been carried out irrespective of the distinction between ES facets.

Our work originates from the motivation to analyze the origins of ES synergies and trade-offs, a necessity for promoting or limiting them. For this, we propose to connect the two previously described research streams, namely the description of ES facets and the formalization of frameworks to analyze ES trade-offs and synergies. By expanding the framework developed by Bennett et al. (2009), we produced the "influence network framework" (INF), which depicts interactions as networks of influences. This descriptive framework captures influence relationships among ES facets in relation to both social (e.g., land allocation) and ecological (e.g., slope) external variables. The INF could be of interest for a wide range of stakeholders, including academics, actors from specific economic sectors (e.g., tourism, forestry), and policy makers. Although a collaborative and iterative building of influence networks was beyond our objectives, we propose this INF as a tool for social learning that could support the appreciation of multiple perceptions and concerns in the management of environmental resources.

In short, we assessed whether the INF, through the simple decomposition of relationships and the consideration of ES facets, could deliver a comprehensive understanding of complex ESrelated issues. We tested its operational potential via a consultative process that aimed at describing major interactions perceived by local stakeholders concerning alpine environmental management. Based on this consultation, the tendency of each category of variables (namely ES categories, biodiversity, social, and ecological variables) to influence the overall system or to be impacted by it was quantified. We calculated the ratio of emitted on received influences and synthesized the results as a general sequence of influence. Lastly, we discuss the advantages and potentials of the framework, illustrated by insights from the French Alps assessment.

\section{METHODS}

\section{The influence network framework (INF)}

To better understand the mechanisms underpinning trade-offs and synergies, Bennett et al. (2009) proposed to distinguish interactions among ES and external variables depending on their direct or indirect (i.e., mediated by another ES) nature. This framework described six configurations resulting from combinations of the strength of ES interactions (weak, medium, strong) and the impact of a driver on pairs of ES (independent or shared). Rives et al. (2012) further adapted this framework to characterize the influence relationships between ES by specifying the nature of interactions (competition or mutual benefit) and their origin (social system or ecological system). To advance from this original framework, we assumed that a more comprehensive understanding of the socialecological system would be gained by formally describing synergies and trade-offs between: (1) ES considering their different facets, (2) biodiversity, and (3) external ecological or social variables (Fig. 1).

External variables were defined as social variables if they were related to human choices, e.g., land allocation choices, policy measures, specific practices in agriculture and forestry, property rights, or evolutions in social demand. They were complemented by ecological variables tightly related to geophysical features, e.g., temperature, slope. These external variables integrate concepts such as drivers of change (Bennett et al. 2009) or pressures (Harrington et al. 2010, Villamagna et al. 2013) and enable the consideration of feedback effects from ES.

The biodiversity variable was singled out to account for the role of particular species, e.g., burrowing animals damaging agricultural production, soil biodiversity responsible for soil fertility. Biodiversity was also considered as a generic term to describe, for example, the general impact of urbanization or the role of biodiversity for landscape aesthetics. Regarding biodiversity in particular, the INF was designed to elucidate: (1) the supporting role of biodiversity for ES supply, (2) the impacts of ES supply on biodiversity, and (3) the social importance of biodiversity, considered with cultural ES (e.g., presence of iconic species).

Influence relationships in the INF were characterized as unilateral when one variable (ES, biodiversity, social, or ecological variable) influenced a second one without major feedback, or as mutual when both variables influenced each other, notwithstanding the facet concerned. We also considered interactions between facets of the same ES, for instance, the shortage in the potential supply of one ES could increase its demand (Fig. 1).

Regarding the nature of influences, positive relationships represent situations in which one variable would strengthen another, for instance, by fostering ES supply or demand or by having a synergistic effect on biodiversity or external variables. Negative influences were used to represent the opposite situation, for instance, conflicting demands from stakeholder groups or tradeoffs between ES. Varying influences were needed to express influences that had both positive and negative aspects and also to describe influences that vary depending on magnitude of change, intensity of practices, etc.

\section{Study area}

Our analysis focused on the French Alps (Fig. 2), which encompass $52149 \mathrm{~km}^{2}$ over nine "départements." The French Alps are the western part of the Alpine arc and their complex topography encompasses elevations from below $100 \mathrm{~m}$ to Mont Blanc culminating at $4810 \mathrm{~m}$. Dominant land-cover types are forests and seminatural areas (67\%), followed by arable lands (27\%) mainly in 
Fig. 1. Influence network framework (INF). The INF describes influence relations between ecosystem services (ES), biodiversity, and external ecological and social variables, within the social-ecological system. Ecosystem services are described explicitly by their three facets: potential supply (-P-), demand (-D-), and use (-U-). Influence relationships are unilateral when one variable influences a second one without major feedback (thin arrows) and mutual when both variables influence each other (bold arrows). Relationships occur between ES (purple arrows), either among the same facets $(\mathrm{a}, \mathrm{b})$ or among distinct facets (a', b'). Interactions among differing facets of the same ES can also occur (a'). Relationships additionally connect ES facets and other variables (orange arrows) with a unilateral influence (1) or mutual influences (2). External variables and biodiversity can similarly interact through unilateral or mutual influences (arrows not shown). All relations can be positive, negative, or of varying influence.

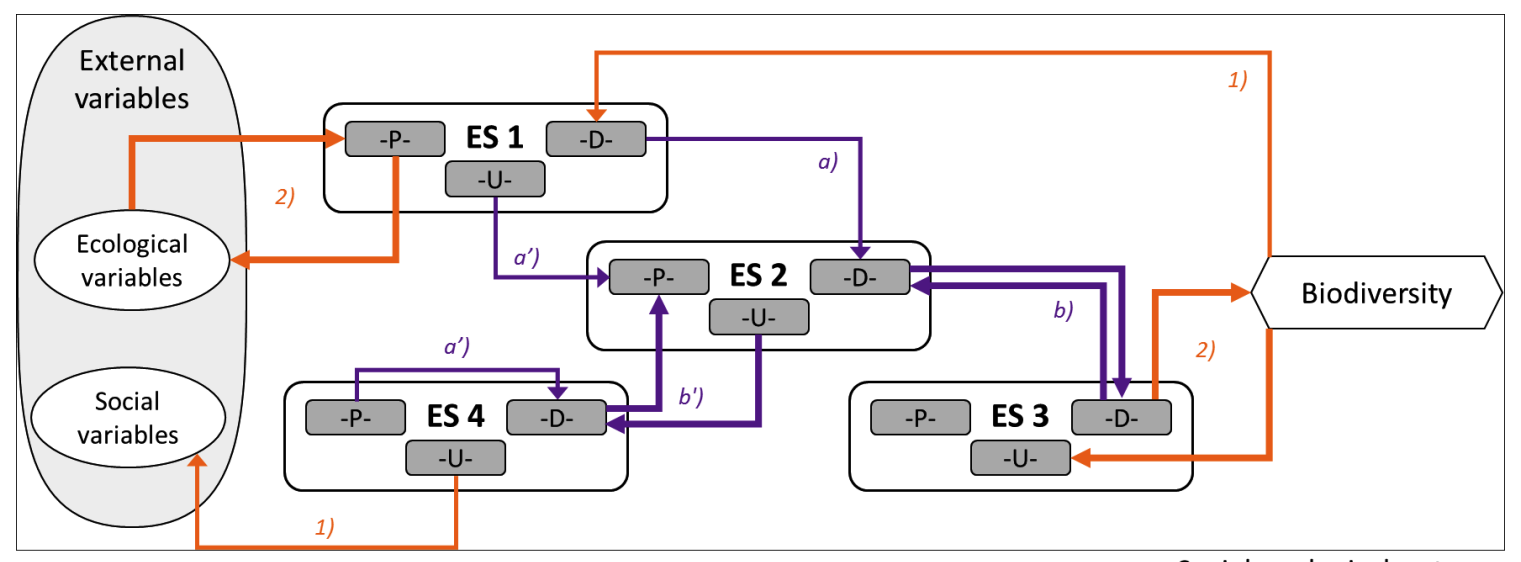

Social-ecological system

the western broad valleys and piedmonts, and concentrating builtup covers $(5 \%)$ over a restricted area (Corine Land Cover 2006). High-density urban areas in the valleys contrast with more isolated or rural areas. The broad latitudinal climate and vegetation gradient have had historical consequences on social dynamics and economic activities (Tappeiner et al. 2008). Because of natural constraints (altitude, climate, slope inclination), the eastern part of the French Alps has been dedicated to mostly extensive livestock farming favoring alpine cultural landscapes. In the south and in the longitudinal valleys of the western Alps, more gentle natural conditions permit mixed or field cropping with higher management intensity. Within this regional matrix, the steepest and most constrained areas, e.g., highly erodible soils, have seen continuous depopulation since World War II, resulting in a sharp decline in farming activities, followed by subsequent natural afforestation. Forms of tourism are also contrasted. In the Northern Alps, tourism intensity is high, mainly during winter, thus having an impact on the sensitive high-altitude areas through infrastructure development. In the Southern Alps, tourism is usually more rural and small scale. Altogether, the diversity of biophysical settings and human uses is responsible for the high variety of biodiversity, ecosystems, and ES across the entire area (Tappeiner et al. 2008, Crouzat et al. 2015).

\section{Data sources and analysis}

Our approach was grounded in a consultative process that applied the INF as a descriptive and analytic tool. Based on qualitative data obtained from regional experts (Appendix 1, Fig. A1.1), we explored how ES were perceived to relate to each other and to external variables in the French Alps.
Fig. 2. The French Alps in France (left). Main land covers in the French Alps (right).

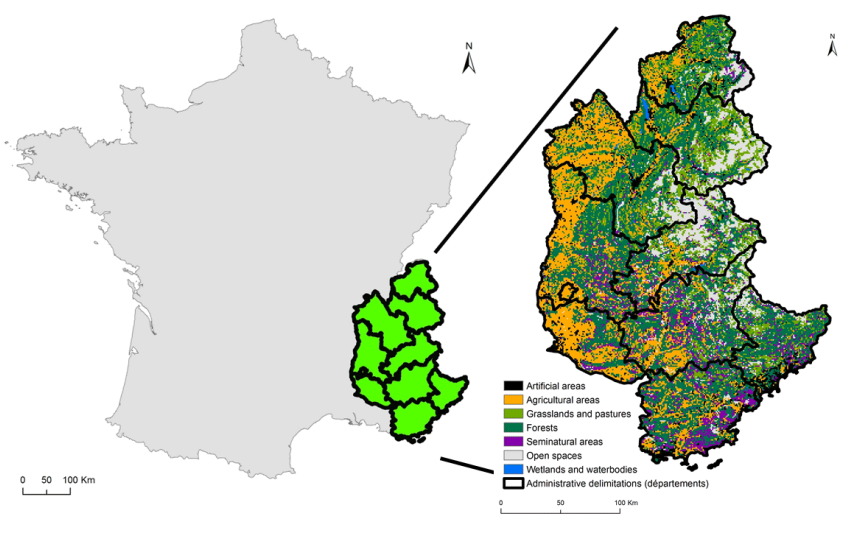

The consultative phase comprised three steps (Fig. 3), for each of which we approached distinct stakeholders. First, eight semistructured interviews were used to develop a comprehensive overview of the main ES and aspects of biodiversity that were either demanded or impacted by important economic sectors related to alpine ecosystems (e.g., forestry, nature tourism, agriculture). Second, based on the first step, 15 stakeholders debated in a focus group the prominent synergies and trade-offs they perceived concerning ES and biodiversity in specific landscapes, i.e., forests, agricultural landscapes, open (semi) natural, spaces and built-up areas. Third, during 12 semistructured individual interviews, interviewees were asked to 
Fig. 3. Consultative process steps and related questions to explore ecosystem service (ES) networks in the French Alps using the influence network framework (INF).

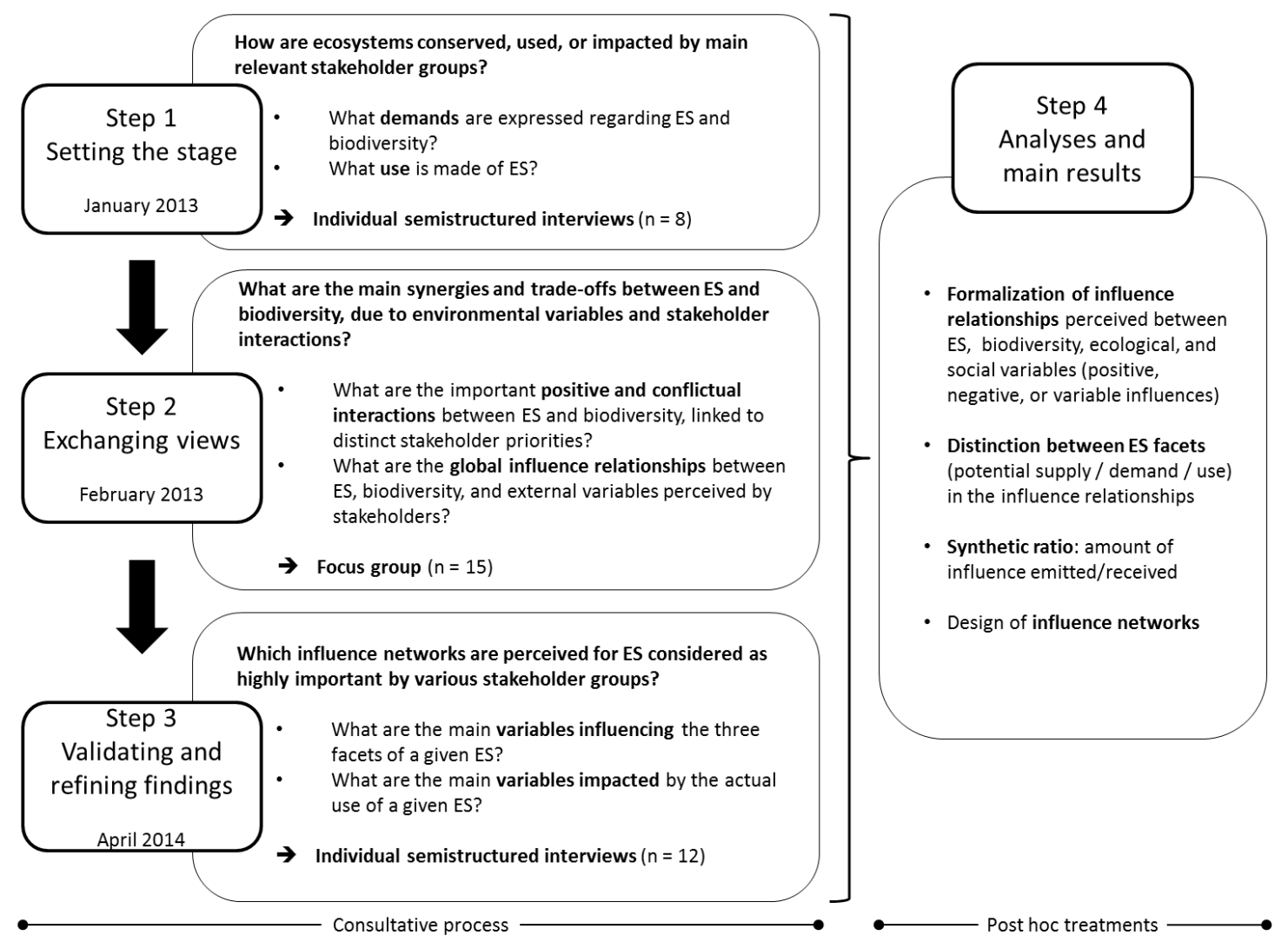

select highly important ES among those previously discussed and then to investigate the main variables influencing and being impacted by their supply. We reached saturation of information after 12 interviews; therefore we estimated that sampling was sufficient (Eisenhardt 1989, Lugnot and Martin 2013).

Semistructured interviews were chosen in the first and third steps because they are known to provide "reliable, comparable qualitative data to get a practicable understanding of stakeholders' knowledge, intentions and actions" (Lugnot and Martin 2013:1147). The present study combines focus groups and individual interviews to gather complementary and reliable information (Kaplowitz and Hoehn 2001). Stakeholder sampling was intentional and reflected the need for information-rich cases (Coyne 1997, Menzel and Buchecker 2013). We maximized the diversity of our resource persons to get a comprehensive overview, following a classical case-study research approach (Eisenhardt 1989). The relationships we depicted are specific to our case study and represent a synthesis of the perceptions of the consulted stakeholders. As with all research based on expert judgement, it cannot be excluded that a different respondent sample would give slightly different results. Indeed, we recognize that the French Alps region supplies other relevant ES (e.g., microclimate regulation) and involves additional external variables, but we are confident that attention to the sampling process from multiple sources, combined with two different consultative techniques mobilized a representative knowledge of the social-ecological system.

The fourth step of our methodological design consisted in post hoc treatments and data analyses. All interviews and discussions were recorded, transcribed, and coded following a deductive qualitative content analysis process (Elo and Kyngäs 2008, Lugnot and Martin 2013). First, we analyzed stakeholder discourses to identify all variables discussed. Second, we formalized pairwise relationships between variables by combining outputs of the three consultative steps. We obtained an influence matrix showing pairwise influences received and emitted (see Appendix 2). During this phase, we specifically attributed influences to ES facets according to stakeholder discourses. We treated influences detected during the individual interviews or during the focus groups equally. We did not discriminate influences based on frequency of mentioning. Third, from the influence matrix, we built influence networks of varying complexity following the INF. These networks focused on one of the variables discussed by stakeholders (e.g., specific ES, such as erosion mitigation; specific aspects of biodiversity. such as wolf presence, or specific external variables, such as urbanization trends) and included the related first-order influence relationships mentioned by stakeholders. Fourth, as a post hoc synthesis of stakeholder perceptions, we calculated the ratio between the number of emitted influences and the number of received 
Fig. 4. Examples of pairwise influences concerning alpine ecosystem services (ES), as perceived by stakeholders during the consultative process, picked from the influence matrix of our case study (Appendix 2). Diagrams represent influences between ES, within the same facet (A) and among facets (B), between ES and biodiversity (C), and between ES and external variables (D). Influences are either unilateral (influence 1, left column) or mutual (influences 2 and 3, right column) and concern all variable categories: provisioning ES (P), cultural ES (C), regulating ES (R), biodiversity (Bd), social variables (SV), and ecological variables (EV). Green arrows represent a positive influence, red arrows a negative influence, and orange arrows describe influences with either positive and negative aspects, or varying ones.

\begin{tabular}{|c|c|c|}
\hline \multicolumn{3}{|c|}{ Pairwise influences proposed by stakeholders and discussed during the consultative process - Justifications are extracted from stakeholder discourses. } \\
\hline $\begin{array}{l}\text { A. } \\
\text { Influences } \\
\text { between ES, } \\
\text { concerning the } \\
\text { same facet }\end{array}$ & $\begin{array}{l}\text { Fire risk } \\
\text { mitigation (R) }\end{array}$ & 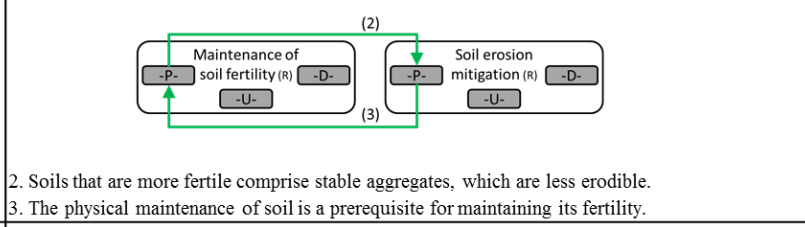 \\
\hline $\begin{array}{l}\text { B. } \\
\text { Influences } \\
\text { between ES, } \\
\text { concerning } \\
\text { different } \\
\text { facets }\end{array}$ & 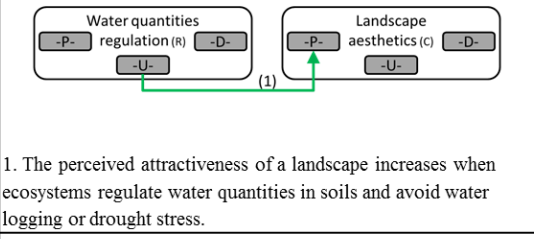 & $\begin{array}{l}\text { 2. The increasing number of people enjoying nature tourism and practicing off-piste can damage } \\
\text { young trees and limit the biophysical potential for wood production. } \\
\text { 3. Actual forest use can both support the potential for nature tourism (e.g., through an increased } \\
\text { accessibility via forest servicing) and diminish it (e.g., negative perception of logging features). }\end{array}$ \\
\hline $\begin{array}{l}\text { C. } \\
\text { Influences } \\
\text { between ES } \\
\text { and } \\
\text { biodiversity }\end{array}$ & $\begin{array}{l}\text { 1. The actual production of hydro energy is negative for the } \\
\text { ecological connectivity and damages habitats in water bodies and } \\
\text { riparian areas. }\end{array}$ & $\begin{array}{l}\text { 2. A high biodiversity is a factor of touristic attractiveness per se and also in relation to increased } \\
\text { recreation opportunities (e.g., observation of deer rut or of large birds of prey, plant picking) } \\
\text { 3. People actually enjoying outdoor tourism can disturb wildlife and damage habitats and plants. }\end{array}$ \\
\hline $\begin{array}{l}\text { D. } \\
\text { Influences } \\
\text { between ES } \\
\text { and external } \\
\text { variables }\end{array}$ & 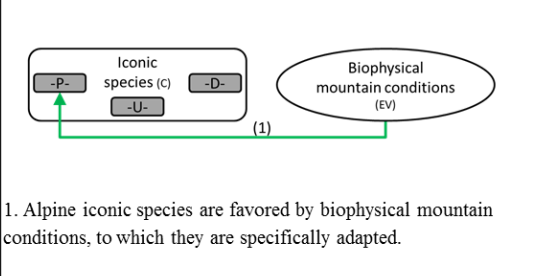 & $\begin{array}{l}\text { 2. Urbanization trends (increased peri-urbanization) increase exposure of populations to } \\
\text { gravitational hazards and thus expand the amount and areas of protection desired. } \\
\text { 3. Urbanization trends benefit from limited exposure to negative impacts from gravitational hazards } \\
\text { while being also limited by restrictions linked to the conservation of protective ecosystems. }\end{array}$ \\
\hline
\end{tabular}

influences for each category of variable in the influence matrix. This ratio, which was standardized between 0 and 1 , quantified "what influences what," despite the fact that categories included nonequal numbers of variables. The higher the ratio, the more the variable influenced the system through multiple pathways; whereas the lower the ratio, the more multiple variables of the system had an impact on the variable.

\section{RESULTS}

\section{Exploring the three facets of ecosystem services}

Stakeholders discussed influence relationships concerning 5 provisioning services, 5 cultural services, and 10 regulating services. Table 1 contains a description of the facets of these ES as they were commonly understood by the stakeholders and synthesized by the research team. Although these definitions are meant to be generic, future users may refine them to reflect a local understanding of ES facets. We clustered the social or ecological features that stakeholders mentioned as interacting with ES into a limited number of external variables (Table 2).

\section{Testing the operational potential of the influence network framework (INF)}

The 216 pairwise relationships mentioned during the consultative process were synthesized in a global influence matrix, explicating the ES facets concerned (Appendix 2, Table A2.1). Picking from these, we exemplify relations using the INF (Fig. 4) within ES facets (diagrams A), between ES facets (diagrams B), between ES and biodiversity (diagrams C), and between ES and external variables (diagrams D).

Interactions were considered unilateral when stakeholders mentioned only one directional influence of perceived prominent importance compared to the (potential) feedback response. For instance, although the stakeholders proposed a negative influence from hydro energy use on biodiversity, they did not mention related feedbacks in which biodiversity could impact hydro energy production (Fig.4.C). Similarly, they mentioned the positive influence of fire risk mitigation to preserve the potential of ecosystems to protect against gravitational hazards, but they did not discuss the opposite relationship (Fig.4.A). The fact that the 
Table 1. Ecosystem services (ES) discussed by stakeholders during the consultative process and specification of their three facets. Three ES categories are represented: provisioning ES (P), cultural ES (C), and regulating ES (R). Note: some ES might require other capital inputs in addition to natural capital to be used (Reyers et al. 2013, Fisher and Eastwood 2016, Palomo et al. 2016).

\begin{tabular}{|c|c|c|c|}
\hline ES & $\begin{array}{l}\text { Potential supply } \\
\text { Ecosystem potential capacity to supply ES } \\
\text { based on the combination of geophysical and } \\
\text { ecological characteristics under current land } \\
\text { use }\end{array}$ & $\begin{array}{l}\text { Demand } \\
\text { Amount of ES desired by various stakeholders } \\
\text { considering the effort (time, money, etc.) } \\
\text { currently required to benefit from it }\end{array}$ & $\begin{array}{l}\text { Use } \\
\text { Amount of ES supply that actually contributes } \\
\text { to fulfilling social demands considering current } \\
\text { social arrangements or regulations }\end{array}$ \\
\hline $\begin{array}{l}\text { Fresh water supply } \\
\text { (P) }\end{array}$ & $\begin{array}{l}\text { Volumes of freshwater that ecosystems have the } \\
\text { biophysical capacity to supply for human } \\
\text { consumption }\end{array}$ & $\begin{array}{l}\text { Total volume of water desired by stakeholders } \\
\text { for multiple uses (irrigation, industry, domestic } \\
\text { consumption, etc.) }\end{array}$ & $\begin{array}{l}\text { Volume of water from the ecosystem actually } \\
\text { used to produce social benefits (increased } \\
\text { agricultural yields, soft drinking water available, } \\
\text { etc.) }\end{array}$ \\
\hline $\begin{array}{l}\text { Agricultural } \\
\text { productions }(\mathrm{P})\end{array}$ & $\begin{array}{l}\text { Quantities and types of harvestable } \\
\text { agricultural products that ecosystems have the } \\
\text { biophysical potential to grow under current } \\
\text { management practices }\end{array}$ & $\begin{array}{l}\text { Quantities and types of agricultural products } \\
\text { desired by stakeholders (local population, } \\
\text { visitors, remote population in case of export of } \\
\text { agricultural products) under current economic } \\
\text { conditions }\end{array}$ & $\begin{array}{l}\text { Crop and fodder quantities that reach local to } \\
\text { global food provision chains }\end{array}$ \\
\hline $\begin{array}{l}\text { Wood production } \\
\text { (P) }\end{array}$ & $\begin{array}{l}\text { Volumes of harvestable timber that ecosystems } \\
\text { have the biophysical potential to grow under } \\
\text { current management practices (accessibility } \\
\text { and profitability constraints) }\end{array}$ & $\begin{array}{l}\text { Total volume of timber desired for multiple } \\
\text { uses (industry, construction, etc.) under current } \\
\text { economic conditions }\end{array}$ & $\begin{array}{l}\text { Amount of wood actually harvested that reach } \\
\text { local to global timber provision chains }\end{array}$ \\
\hline Wood energy $(\mathrm{P})$ & $\begin{array}{l}\text { Energetic potential of logging residues from } \\
\text { wood harvesting and of harvestable fuel } \\
\text { sources under current management practices }\end{array}$ & $\begin{array}{l}\text { Quantity of energy from renewable and local } \\
\text { resources desired by local and remote } \\
\text { stakeholders under current economic } \\
\text { conditions }\end{array}$ & $\begin{array}{l}\text { Quantity of biomass energy actually generated } \\
\text { by forest products }\end{array}$ \\
\hline Hydro energy (P) & $\begin{array}{l}\text { Quantity of hydro energy potentially produced } \\
\text { by medium to large water bodies in steep areas }\end{array}$ & $\begin{array}{l}\text { Quantity of hydro energy desired by local and } \\
\text { remote stakeholders under current economic } \\
\text { conditions }\end{array}$ & $\begin{array}{l}\text { Quantity of energy actually produced from } \\
\text { hydroelectric plants that reach electricity } \\
\text { provision chains }\end{array}$ \\
\hline Leisure hunting $(\mathrm{C})$ & Abundance and diversity of wild game species & $\begin{array}{l}\text { Abundance and diversity of game desired by } \\
\text { hunters in accessible areas where the game and } \\
\text { hunting are not disturbed by other activities }\end{array}$ & $\begin{array}{l}\text { Amount of game actually killed, depending on } \\
\text { hunting quotas and successful hunts }\end{array}$ \\
\hline Iconic species $(\mathrm{C})$ & $\begin{array}{l}\text { Abundance and diversity of socially valued } \\
\text { wild species }\end{array}$ & $\begin{array}{l}\text { Abundance and diversity of iconic species } \\
\text { desired by society (e.g., official threat } \\
\text { thresholds such as Red List status or } \\
\text { abundance values from individual preferences) }\end{array}$ & $\begin{array}{l}\text { Actual presence of iconic species in desired } \\
\text { areas }\end{array}$ \\
\hline $\begin{array}{l}\text { Landscape } \\
\text { aesthetics }(\mathrm{C})\end{array}$ & $\begin{array}{l}\text { Potential landscape aesthetic quality, } \\
\text { depending on landscape metrics and their } \\
\text { social perception (e.g., alpine cultural } \\
\text { landscapes shaped by agriculture, forestry, and } \\
\text { outdoor tourism activities) }\end{array}$ & $\begin{array}{l}\text { Desired state of the landscape at specific } \\
\text { locations }\end{array}$ & $\begin{array}{l}\text { Actual presence of landscapes meeting } \\
\text { aesthetic aspirations of stakeholders }\end{array}$ \\
\hline Nature tourism $(\mathrm{C})$ & $\begin{array}{l}\text { Potential for outdoor activities depending on } \\
\text { attractiveness and equipment (e.g. trails, } \\
\text { climbing sites, etc.) of (semi)natural areas }\end{array}$ & $\begin{array}{l}\text { Sufficient availability of accessible, secure, and } \\
\text { attractive locations for outdoor activities }\end{array}$ & $\begin{array}{l}\text { Actual outdoor tourism practices experienced } \\
\text { by people in desired areas }\end{array}$ \\
\hline $\begin{array}{l}\text { Environmental } \\
\text { education }(\mathrm{C})\end{array}$ & $\begin{array}{l}\text { Potential for environmental education } \\
\text { depending on landscape characteristics, } \\
\text { biodiversity features, and communication } \\
\text { opportunities (educational trails, theme tours, } \\
\text { etc.) }\end{array}$ & $\begin{array}{l}\text { Sufficient availability of accessible educational } \\
\text { opportunities desired by stakeholders }\end{array}$ & $\begin{array}{l}\text { Actual environmental education opportunities } \\
\text { experienced by people in desired areas }\end{array}$ \\
\hline $\begin{array}{l}\text { Soil erosion } \\
\text { mitigation }(\mathrm{R})\end{array}$ & $\begin{array}{l}\text { Amount of soil retention and protection } \\
\text { offered by ecosystems under current land use } \\
\text { and management practices }\end{array}$ & $\begin{array}{l}\text { Desired level of soil erosion control at relevant } \\
\text { locations according to stakeholders }\end{array}$ & $\begin{array}{l}\text { Actual erosion control by ecosystems that } \\
\text { contributes to limiting negative impacts on } \\
\text { sensitive areas }\end{array}$ \\
\hline $\begin{array}{l}\text { Gravitational } \\
\text { hazards mitigation } \\
\text { (R) }\end{array}$ & $\begin{array}{l}\text { Presence of natural vegetation protective } \\
\text { elements (forests, pastures) under current land } \\
\text { use and management practices }\end{array}$ & $\begin{array}{l}\text { Desired level of gravitational hazard mitigation } \\
\text { at relevant locations according to stakeholders }\end{array}$ & $\begin{array}{l}\text { Actual hazard mitigation that contributes to } \\
\text { limiting negative impacts in sensitive areas }\end{array}$ \\
\hline $\begin{array}{l}\text { Fire risk mitigation } \\
(\mathrm{R})\end{array}$ & $\begin{array}{l}\text { Presence of specific vegetation and land } \\
\text { configuration reducing fire spread under } \\
\text { current land use and management practices }\end{array}$ & $\begin{array}{l}\text { Desired level of protection from fire damage at } \\
\text { relevant locations according to stakeholders }\end{array}$ & $\begin{array}{l}\text { Actual protection from fire damage that } \\
\text { contributes to limiting negative impacts in } \\
\text { sensitive areas }\end{array}$ \\
\hline $\begin{array}{l}\text { Flood risk } \\
\text { mitigation }(\mathrm{R})\end{array}$ & $\begin{array}{l}\text { Ecosystem ability to buffer river discharge after } \\
\text { heavy precipitation events, depending on plant } \\
\text { cover and edaphic conditions }\end{array}$ & $\begin{array}{l}\text { Desired level of protection from flood damage } \\
\text { at relevant locations according to stakeholders }\end{array}$ & $\begin{array}{l}\text { Actual protection from flood damage that } \\
\text { contributes to limiting negative impacts in } \\
\text { sensitive areas }\end{array}$ \\
\hline $\begin{array}{l}\text { Maintenance of } \\
\text { water quality }(\mathrm{R})\end{array}$ & $\begin{array}{l}\text { Ecosystem ability to retain pollutants and } \\
\text { nutrients from water fluxes, depending on plant } \\
\text { cover and edaphic conditions considering } \\
\text { current environmental disturbances (e.g., } \\
\text { pollution sources) }\end{array}$ & $\begin{array}{l}\text { Desired level of pollutant and nutrient } \\
\text { retention required to meet fresh water quality } \\
\text { standards (set by legislation or according to } \\
\text { stakeholder preferences) }\end{array}$ & $\begin{array}{l}\text { Actual pollutant retention that contributes to } \\
\text { meeting fresh water quality standards }\end{array}$ \\
\hline $\begin{array}{l}\text { Maintenance of soil } \\
\text { fertility (R) }\end{array}$ & $\begin{array}{l}\text { Ecosystem ability to store and recycle nutrients } \\
\text { needed for crop and pasture growth, depending } \\
\text { on above-ground biomass, soil biodiversity, and } \\
\text { soil parameters }\end{array}$ & $\begin{array}{l}\text { Desired level of nutrients necessary in situ to } \\
\text { grow crop and pasture at relevant locations } \\
\text { according to stakeholders }\end{array}$ & $\begin{array}{l}\text { Actual amount of nutrients that contributes to } \\
\text { limiting external fertilizers and to supporting } \\
\text { crop and pasture growth }\end{array}$ \\
\hline
\end{tabular}


Actual benefits from biological pest control (increased yields, reduced use of pesticides, etc.)

Actual benefits from wild pollinators (ensuring the yields and quality of agricultural products)

Actual regulation of water quantities that contributes to limiting negative impacts in sensitive areas (limited runoff, stable water stock in soils, and stable water flows) Actual carbon storage and sequestration that contributes to meeting greenhouse gas concentration aspirations relationship appears as unilateral does not imply that the unmentioned feedback relationship does not exist.

Alternatively, stakeholders highlighted mutual influences that included feedback responses. For example, stakeholders gave biodiversity as a factor of attractiveness for nature tourism and they attributed a negative feedback because of the damages caused by outdoor practitioners on plants and animals (Fig.4.C). Similarly, stakeholders discussed mutual influences between nature tourism and wood production, because the supply of each ES appeared conditioned by the other's management (Fig.4.B).

\section{Example of an influence network framework focused on leisure hunting}

By aggregating pairwise influences, we were able to design influence networks depicting explicitly the many parameters and mechanisms related to trade-offs and synergies between ES and biodiversity. Figure 5 proposes such a network focused on leisure hunting.

The leisure hunting influence network showed shared influences with all ES categories and with ecological and social variables. Some influences concerned single ES facets, whereas others connected different facets, e.g., use of leisure hunting and potential supply of biological control of pests.

The INF highlighted opportunities for stakeholder synergies. As an example, the supply of resources and habitats for game species by agricultural areas could prompt farmers to adopt wildlife friendly practices to enhance game abundance, i.e., leisure hunting potential supply. This opportunity has actually been formalized through the Agrifaune program through which the hunters' federation supports voluntary farmers. In addition, the INF exposed the reasons for conflicts between stakeholders. The conflict between hunters and nature tourists arose from antagonistic demands, with hunters requiring that game be undisturbed by tourists and nature tourists feeling insecure during hunting periods. Managing this situation would be a social process, requiring stakeholder conciliation and more formal rules for both activities. These examples illustrate how differentiating between ES facets allowed us to precisely identify the origins of ES synergies and trade-offs, which has been considered essential to identify "ecological leverage points where small management investments can yield substantial benefits" (Bennett et al. 2009:1398).
Table 2. Social and ecological variables mentioned by interviewees to describe influence relationships with ecosystem services (ES) and biodiversity in the alpine social-ecological system.

\begin{tabular}{ll}
\hline \hline Social variables & Ecological variables \\
\hline Policy (including protective status) & $\begin{array}{l}\text { Biophysical conditions of alpine areas } \\
\text { (slope, altitude, climate, seasonality, } \\
\text { vegetation types, etc.) } \\
\text { Landscape diversity: heterogeneous and } \\
\text { open landscapes } \\
\text { Climate change (changes in } \\
\text { precipitation, temperatures, etc., in } \\
\text { relation to human activities) }\end{array}$ \\
$\begin{array}{l}\text { Social changes (e.g., population age } \\
\text { structure, balance between rural and } \\
\text { urban population, evolution in social } \\
\text { demand, etc.) }\end{array}$ & $\begin{array}{l}\text { Economic profitability and structure } \\
\text { of the economic sector }\end{array}$ \\
$\begin{array}{l}\text { Diversity and management of human } \\
\text { uses regarding ecosystems } \\
\text { (agriculture, forestry, etc.) }\end{array}$ & \\
\hline
\end{tabular}

\section{Overall influence ratios}

As a further post hoc treatment, the ratio of emitted influences on received influences showed distinct features across categories of variables (Table 3). External social and ecological variables had the highest standardized ratios (1 and 0.950 , respectively): stakeholders mentioned that they influenced ES and biodiversity in numerous ways, but these remained largely unaffected by other variables. The reasons why external variables were considered unaffected varied: ecological variables were described as quasi fixed because of biophysical constraints (e.g., soils, slopes) while social variables reflected the current socio-cultural setting and were dynamic. Both provisioning and cultural services had intermediate standardized ratios (0.078 and 0.040 , respectively), meaning that they both received and emitted a fairly equivalent number of influences. Finally, regulating services and biodiversity presented the lowest standardized ratio (0.008 and 0, respectively), showing that stakeholders perceived them as receiving multiple influences from the whole system while emitting a limited number of influences. Thus, as an overall influence sequence, we classified social and ecological variables as mostly influencing variables, cultural and provisioning services as target variables, and biodiversity and regulating services as impacted variables. An additional analysis of influence ratios is proposed in Appendix 3 presenting ratios between pairs of categories rather than global ratios, with overall consistent, although more detailed, results. 
Fig. 5. Example of an influence network centered around leisure hunting, as discussed by stakeholders during the consultative process. This network is built from a selection of first-order relations related to the leisure hunting ecosystem service (ES; Appendix 2). Influences concern all variable categories: provisioning ES (P), cultural ES (C), regulating ES (R), biodiversity, social variables (SV), and ecological variables (EV). Green arrows represent a positive influence or a synergy, red arrows a negative influence or an antagonism, and orange arrows describe influences with either positive and negative aspects, or varying ones.

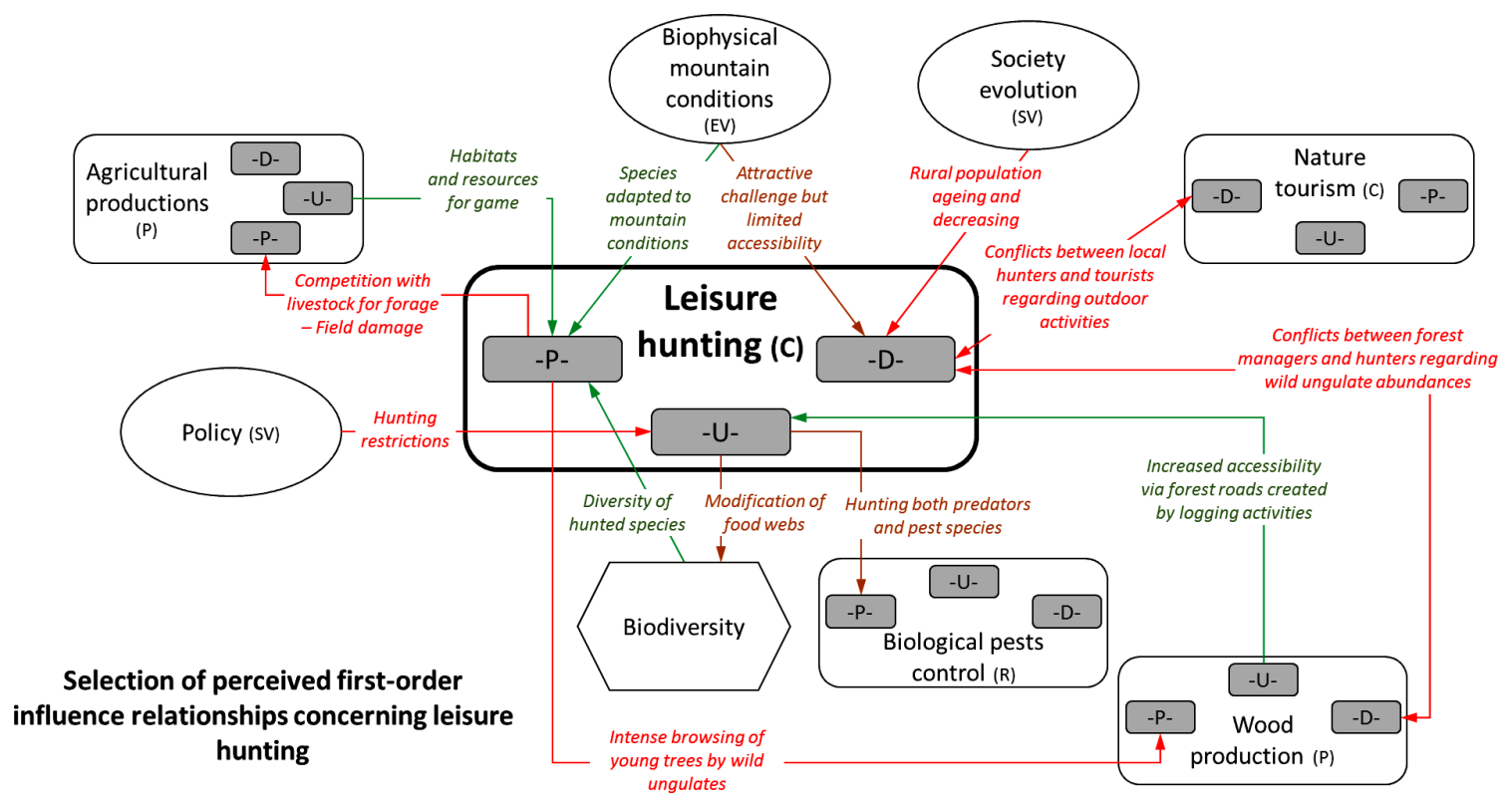

Table 3. Classification of standardized global influence ratio as a synthetic outcome of the French Alps consultative process (number of influences emitted by a category divided by the number of influences received by the same category; standardization by subtracting the minimum value to each ratio and dividing by the range of values). ES = ecosystem services.

\begin{tabular}{lcc}
\hline \hline Category & $\begin{array}{c}\text { Standardized global } \\
\text { influence ratio } \\
\text { (perceived) } \\
\text { range: } 0-1\end{array}$ & Classification (perceived) \\
\hline Social variables & 1 & Influencing variables \\
Ecological variables & 0.950 & Influencing variables \\
Provisioning ES & 0.078 & Target variables \\
Cultural ES & 0.040 & Target variables \\
Regulating ES & 0.008 & Impacted variables \\
Biodiversity & 0 & Impacted variables \\
\hline
\end{tabular}

\section{DISCUSSION}

We demonstrated that the INF is suitable for qualitatively describing both simple relationships and complex networks of trade-offs and synergies between ES, respective to their distinct facets, and other components of the social-ecological system. Furthermore, the INF allowed us to synthesize how stakeholders perceived the links between ecological and social systems. We discussed the main insights at conceptual and operational levels, considering four issues: (1) the advantages of making an explicit distinction between the three ES facets, (2) the origins and consequences of discrepancies between actual and perceived ecological influences, (3) the interests of integrating multiple stakeholder perceptions, and (4) challenges and opportunities of addressing complexity.

Advantages of multifaceted ecosystem services analysis

By going a step further than widely adopted ES categories, the inclusion of ES facets in the INF holds at least four advantages. First, our analysis demonstrated that distinguishing ES facets is necessary to design management measures appropriate to address ES trade-offs based on an in-depth understanding of their determinants. This applies equally for interactions between facets of a given ES (e.g., diversification of demands for nature tourism can lead to conflicting expectations) or for interactions between ES. For instance, use by nature tourism was described as negative for the potential wood production supply, because increasing offpiste skiing limits wood production by damaging young trees. A conciliation process could foster outdoor practices more respectful of seedlings.

Second, considering ES facets in an explicit way is a relevant step toward a more even depiction of the social and ecological systems and of their interactions, which in turn is required for adaptive spatial planning (Bennett et al. 2009, Chan et al. 2012, Ban et al. 2013, Karrasch et al. 2014). To date, much more work has addressed ecological dimensions than social dimensions (Bagstad et al. 2014), yet both need more balanced treatment (Spangenberg et al. 2014, Bennett et al. 2015).

Third, by explicitly accounting for ES facets in the INF, we analyzed multiple spatial scales, acknowledging that social scales cut across biological boundaries (Hein et al. 2006). As an example, 
agricultural production is supplied at field scale; its demand arises from a larger scale depending on the location of beneficiaries; and its use depends on both the farmer's local practices and on external factors at a larger scale (e.g., European and national policies). Consequently, interactions between ES also cut across multiple scales that must be considered for effective management (Willemen et al. 2012).

Fourth, by specifically including the use facet, the INF integrated external variables whose influence could have been otherwise overlooked (Spangenberg et al. 2014), e.g., the positive influence of wood production on the use of leisure hunting through increased accessibility on logging roads (Fig. 4). Moreover, policy was sometimes observed to impact only the use facet. For instance, to sustain other ecosystem functions and services that depend on minimum downstream flows, environmental legislation in the French Alps reduces the use of hydro energy power regardless of its potential supply or demand.

Discrepancies between perceived and actual ecological influences The sequence of influence identified through our participative process (Table 3 ) showed that regulating services and biodiversity were overall described as impacted variables. But influences perceived by stakeholders may differ from actual ones, because regulating services are essential for ensuring ecosystem resilience and avoiding reductions in the supply of other ES (Bennett et al. 2009, Hauck et al. 2013, Villamagna et al. 2013). For instance, although agricultural production was perceived to have an impact on the potential supply of pollination by wild pollinators, the positive influence from pollination to agricultural production was not mentioned, although the absence of insect pollination would decrease total European crop production by $\sim 30 \%$ (Zulian et al. 2013). This result is consistent with other analyses of stakeholder perceptions, for instance, revealing a lack of consideration of natural hazard mitigation in the Krummhörn region, Germany (Karrasch et al. 2014), or the undervaluation of biodiversity in the Almeria province, Spain (Castro et al. 2011).

Three hypotheses could explain this lack of expert appreciation. First, stakeholders could take regulating services for granted in areas of high environmental quality, such as the French Alps (EEA 2002, Crouzat et al. 2015) in which the ecosystem's ability to supply ES, and mostly provisioning and cultural ES, may not have been degraded (yet) to perceived threatening levels (Abson and Termansen 2011, Villamagna et al. 2013).

Second, authors observed that stakeholders had greater difficulty appreciating the importance of regulating services and biodiversity (Lewan and Söderqvist 2002, Villamagna et al. 2013): these are considered out of their sphere of experience and perception (Iniesta-Arandia et al. 2014). Indeed, these are often intermediate services contributing to the supply of other ES rather than ES from which stakeholders directly benefit (Boyd and Banzhaf 2007, Fisher et al. 2009, Felipe-Lucía et al. 2015). The same reasoning could apply to biodiversity. Thus, our results can be considered representative of the current perception of environmental resources by a general audience, but might not be consistent with scientific knowledge.

Third, some stakeholders trust technological solutions to compensate for negative budgets between ES supply and societal demand (Schneiders et al. 2012). For example, protective dikes can mitigate floods, commercial beekeepers can be hired when wild pollinators are insufficient, and mineral fertilizers can be used to replenish depleted soils. However, the fact that ES might be replaceable by technology is a long-lasting debate between technological optimists and prudent sceptics (Costanza et al. 1997). Evidence suggests that technology can be helpful to enhance ES, but remains insufficient in numerous cases to replace them, in absolute terms or at costs affordable for society (Fitter 2013). In any case, relying on technological solutions requires informed decisions, which in this instance is that stakeholders understand the role of regulating services and biodiversity.

\section{Uncovering multiple perceptions of the social-ecological system}

Possible options to overcome the above bias include: (1) careful attention to the stakeholders involved in the consultation, and (2) colearning opportunities between stakeholders. To obtain a realistic and integrative description of the social-ecological system, consultations on ES influence networks need to deliberately consider the diversity of stakeholders and organizations related to the issue discussed (Lamarque et al. 2011, Bennett et al. 2015). Stakeholders hold various priorities in environmental management and have varying perceptions and knowledge about social-ecological systems (e.g., Castro et al. 2011, Lugnot and Martin 2013, Iniesta-Arandia et al. 2014). We insist that the nature and complexity of INF outputs should be considered as a collective production reflecting the panel of stakeholders consulted.

The diversity of stakeholders and of their understanding of the social-ecological system fosters opportunities for colearning. Using the INF as a supporting tool to share the collective pool of knowledge among stakeholders, including that of scientists, appears as a necessary step to raise environmental awareness, overcome biased perceptions, and ultimately develop a shared understanding of the system. For instance, although we sometimes aggregated contrasting influences expressed by stakeholders as "varying," exposing explicitly differing opinions on the nature of a given influence represents an alternative entry point on territorial conflicts that could be used as a tool for collective learning (Lamarque et al. 2014, Felipe-Lucía et al. 2015). Building a common understanding of the social-ecological system could facilitate subsequent collective management processes.

Involving stakeholders with relevant social and ecological expertise and offering opportunities for colearning is therefore necessary to avoid enforcing incomplete or inaccurate perceptions from biased sampling (Sutherland et al. 2013). The social roles of scientists using this framework could be twofold: first, to propose supporting frameworks and boundary objects of help to address complex issues in transdisciplinary ways (Barnaud and Antona 2014, Castella et al. 2014); second, to ensure that knowledge brokers with adequate skills, and in particular ecological knowledge, could participate in the consultation.

One pitfall of the INF approach is the exponential increase in complexity as new variables and stakeholders are integrated into the network. Although influence relationships between pairs of variables remained simple (Fig. 4), the leisure-hunting example highlighted the large complexity of real systems (Fig. 5). Therefore a balance is needed to avoid simplistic messages and provide graspable but still comprehensive information for 
environmental management. Many tools can be used for this purpose, including participative mental models (Moreno et al. 2014), fuzzy cognitive maps (Kok 2009), bayesian belief networks (Landuyt et al. 2013), social network analysis (Hicks et al. 2013), and influence networks. A collective and iterative building of influence networks appears to be a promising option for identifying and prioritizing relationships that prominently participate in the issue at hand. We suggest that first-order relationships should be included as well as second- or even thirdorder relationships if they contribute information relevant to management. To circumvent the variables and orders of influence to be included, an initial agreement on the specific issue of focus (e.g., management of the multifunctionality of forest areas, interactions between agricultural productions, nature tourism, and biodiversity) and on the objectives of the consultation (e.g., increase understanding, support dialogue along stakeholders, propose management options) are a prerequisite.

\section{Governing complex social-ecological systems}

Finally, in-depth understanding of ES trade-offs and synergies can support the governance analysis of environmental issues. This is relevant because trade-offs between ES can be worsened by conflicting goals of different policy instruments. For instance in Europe, food production supported by the Common Agricultural Policy can conflict with the maintenance of water quality pursued by the Water Framework Directive (Hauck et al. 2013). Additionally, the frequent mention of policy as a driver of ES interactions in our analyses highlighted the need to relate understanding of ES trade-offs to governance issues (Briner et al. 2013). Such governance analysis has been successfully implemented for single ES with participative mental models (Moreno et al. 2014). We anticipate that a main interest of the INF lies in its suitability for, as a next step, mapping policy networks upon ES networks, thus providing innovative and effective understanding of the governance of complex systems.

Responses to this article can be read online at: http://www.ecologyandsociety.org/issues/responses. $\mathrm{php} / 8494$

\section{Acknowledgments:}

This work was funded by ERAnet BiodivERs A project CONNECT, with support from the French Agence Nationale pour la Recherche and OPERAs FP7-ENV-2012-two-stage-308393. Authors thank Fabien Quétier, Pénélope Lamarque, Adeline Bierry, and Caroline Devaux for support during the consultative process. We are grateful to all stakeholders who were so kind to share their perspectives with us.

\section{LITERATURE CITED}

Abson, D. J., and M. Termansen. 2011. Valuing ecosystem services in terms of ecological risks and returns. Conservation Biology 25(2):250-258. http://dx.doi.org/10.1111/j.1523-1739.2010.01623. $\underline{x}$

Anderson, B. J., P. R. Armsworth, F. Eigenbrod, C. D. Thomas, S. Gillings, A. Heinemeyer, D. B. Roy, and K. J. Gaston. 2009.
Spatial covariance between biodiversity and other ecosystem service priorities. Journal of Applied Ecology 46(4):888-896. http:// dx.doi.org/10.1111/j.1365-2664.2009.01666.x

Bagstad, K. J., F. Villa, D. Batker, J. Harrison-Cox, B. Voigt, and G. W. Johnson. 2014. From theoretical to actual ecosystem services: mapping beneficiaries and spatial flows in ecosystem service assessments. Ecology And Society 19(2):64. http://dx.doi. org/10.5751/es-06523-190264

Bai, Y., C. Zhuang, Z. Ouyang, H. Zheng, and B. Jiang. 2011. Spatial characteristics between biodiversity and ecosystem services in a human-dominated watershed. Ecological Complexity 8(2):177-183. http://dx.doi.org/10.1016/j.ecocom.2011.01.007

Ban, N. C., M. Mills, J. Tam, C. C. Hicks, S. Klain, N. Stoeckl, M. C. Bottrill, J. Levine, R. L. Pressey, T. Satterfield, and K. M. A. Chan. 2013. A social-ecological approach to conservation planning: embedding social considerations. Frontiers in Ecology and the Environment 11(4):194-202. http://dx.doi.org/10.1890/110205

Barnaud, C., and M. Antona. 2014. Deconstructing ecosystem services: uncertainties and controversies around a socially constructed concept. Geoforum 56:113-123. http://dx.doi. org/10.1016/j.geoforum.2014.07.003

Bastian, O., D. Haase, and K. Grunewald. 2012. Ecosystem properties, potentials and services - the EPPS conceptual framework and an urban application example. Ecological Indicators 21:7-16. http://dx.doi.org/10.1016/j.ecolind.2011.03.014

Bennett, E. M., G. D. Peterson, and L. J. Gordon. 2009. Understanding relationships among multiple ecosystem services. Ecology Letters 12(12):1394-1404. http://dx.doi.org/10.1111/ j.1461-0248.2009.01387.x

Bennett, E. M., W. Cramer, A. Begossi, G. Cundill, S. Díaz, B. N. Egoh, I. R. Geijzendorffer, C. B. Krug, S. Lavorel, E. Lazos, L. Lebel, B. Martín-López, P. Meyfroidt, H. A. Mooney, J. L. Nel, U. Pascual, K. Payet, N. Pérez Harguindeguy, G. D. Peterson, A.H. Prieur-Richard, B. Reyers, P. Roebeling, R. Seppelt, M. Solan, P. Tschakert, T. Tscharntke, B. L. Turner II, P. H. Verburg, E. F. Viglizzo, P. C. L. White, and G. Woodward. 2015. Linking biodiversity, ecosystem services, and human well-being: three challenges for designing research for sustainability. Current Opinion in Environmental Sustainability 14:76-85. http://dx.doi. org/10.1016/j.cosust.2015.03.007

Boyd, J., and S. Banzhaf. 2007. What are ecosystem services? The need for standardized environmental accounting units. Ecological Economics 63(2):616-626. http://dx.doi.org/10.1016/i. ecolecon.2007.01.002

Briner, S., R. Huber, P. Bebi, C. Elkin, D. R. Schmatz, and A. Grêt-Regamey. 2013. Trade-offs between ecosystem services in a mountain region. Ecology And Society 18(3):35. http://dx.doi. org/10.5751/es-05576-180335

Burkhard, B., F. Kroll, S. Nedkov, and F. Müller. 2012. Mapping ecosystem service supply, demand and budgets. Ecological Indicators 21:17-29. http://dx.doi.org/10.1016/j.ecolind.2011.06.019

Castella, J. C., J. Bourgoin, G. Lestrelin, and B. Bouahom. 2014. A model of the science-practice-policy interface in participatory land-use planning: lessons from Laos. Landscape Ecology 29:1095-1107. http://dx.doi.org/10.1007/s10980-014-0043-x 
Castro, A. J., B. Martín-López, M. García-LLorente, P. A. Aguilera, E. López, and J. Cabello. 2011. Social preferences regarding the delivery of ecosystem services in a semiarid Mediterranean region. Journal of Arid Environments 75 (11):1201-1208. http://dx.doi.org/10.1016/j.jaridenv.2011.05.013

Chan, K. M. A., A. D. Guerry, P. Balvanera, S. Klain, T. Satterfield, X. Basurto, A. Bostrom, R. Chuenpagdee, R. Gould, B. S. Halpern, N. Hannahs, J. Levine, B. Norton, M. Ruckelshaus, R. Russell, J. Tam, and U. Woodside. 2012. Where are cultural and social in ecosystem services? A framework for constructive engagement. BioScience 62(8):744-756. http://dx.doi.org/10.1525/ bio.2012.62.8.7

Costanza, R., J. H. Cumberland, H. Daly, R. Goodland, R. B. Norgaard, I. Kubiszewski, and C. Franco. 1997. An introduction to ecological economics. St. Lucie, Boca Raton, Florida, USA.

Coyne, I. T. 1997. Sampling in qualitative research. Purposeful and theoretical sampling; merging or clear boundaries? Journal of Advanced Nursing 26(3):623-630. http://dx.doi.org/10.1046/ j.1365-2648.1997.t01-25-00999.x

Crouzat, E., M. Mouchet, F. Turkelboom, C. Byczek, J. Meersmans, F. Berger, P. J. Verkerk, and S. Lavorel. 2015. Assessing bundles of ecosystem services from regional to landscape scale: insights from the French Alps. Journal of Applied Ecology 52(5):1145-1155. http://dx.doi.org/10.1111/1365-2664.12502

Eisenhardt, K. M. 1989. Building theories from case study research. Academy of Management Review 14(4):532-550.

Elo, S., and H. Kyngäs. 2008. The qualitative content analysis process. Journal of Advanced Nursing 62(1):107-115. http://dx.doi. org/10.1111/j.1365-2648.2007.04569.X

European Environmental Agency (EEA). 2002. The alpine region - mountains of Europe. European Environmental Agency, Copenhagen, Denmark. [online] URL: http://www.eea.europa. eu/publications/report 20020524 154909/biogeographical-regionsin-europe/alpine.pdf

Felipe-Lucía, M. R., B. Martín-López, S. Lavorel, L. BerraqueroDíaz, J. Escalera-Reyes, J., and F. A. Comín. 2015. Ecosystem services flows: why stakeholders' power relationships matter. PLoS ONE 10(7):e0132232. http://dx.doi.org/10.1371/journal. pone. 0132232

Fisher, A., and A. Eastwood. 2016. Coproduction of ecosystem services as human-nature interactions - an analytical framework. Land Use Policy 52:41-50. http://dx.doi.org/10.1016/j. landusepol.2015.12.004

Fisher, B., R. K. Turner, and P. Morling. 2009. Defining and classifying ecosystem services for decision making. Ecological Economics 68(3):643-653. http://dx.doi.org/10.1016/j. ecolecon.2008.09.014

Fitter, A. H. 2013. Are ecosystem services replaceable by technology? Environmental and Resource Economics 55:513-524. http://dx.doi.org/10.1007/s10640-013-9676-5

García-Nieto, A. P., M. García-Llorente, I. Iniesta-Arandia, and B. Martín-López. 2013. Mapping forest ecosystem services: from providing units to beneficiaries. Ecosystem Services 4:126-138. http://dx.doi.org/10.1016/j.ecoser.2013.03.003
Geijzendorffer, I, B. Martín-López, and P. K. Roche. 2015. Improving the identification of mismatches in ecosystem services assessments. Ecological Indicators 52:320-331. http://dx.doi. org/10.1016/j.ecolind.2014.12.016

Harrington, R., C. Anton, T. P. Dawson, F. de Bello, C. K. Feld, J. R. Haslett, T. Kluvánkova-Oravská, A. Kontogianni, S. Lavorel, G. W. Luck, M. D. A. Rounsevell, M. J. Samways, J. Settele, M. Skourtos, J. H. Spangenberg, M. Vandewalle, M. Zobel, and P. A. Harrison. 2010. Ecosystem services and biodiversity conservation: concepts and a glossary. Biodiversity and Conservation 19(10):2773-2790. http://dx.doi.org/10.1007/ s10531-010-9834-9

Hauck, J., C. Görg, R. Varjopuro, O. Ratamäki, and K. Jax. 2013. Benefits and limitations of the ecosystem services concept in environmental policy and decision making: some stakeholder perspectives. Environmental Science and Policy 25:13-21. http:// dx.doi.org/10.1016/j.envsci.2012.08.001

Hein, L., K. van Koppen, R. S. de Groot, and E. C. van Ierland. 2006. Spatial scales, stakeholders and the valuation of ecosystem services. Ecological Economics 57(2):209-228. http://dx.doi. org/10.1016/j.ecolecon.2005.04.005

Hicks, C. C., N. A. J. Graham, and J. E. Cinner. 2013. Synergies and tradeoffs in how managers, scientists, and fishers value coral reef ecosystem services. Global Environmental Change 23 (6):1444-1453. http://dx.doi.org/10.1016/j.gloenvcha.2013.07.028

Iniesta-Arandia, I., M. García-Llorente, P. A. Aguilera, C. Montes, and B. Martín-López. 2014. Socio-cultural valuation of ecosystem services: uncovering the links between values, drivers of change, and human well-being. Ecological Economics 108:36-48. http://dx.doi.org/10.1016/j.ecolecon.2014.09.028

Kandziora, M., B. Burkhard, and F. Müller. 2013. Interactions of ecosystem properties, ecosystem integrity and ecosystem service indicators - a theoretical matrix exercise. Ecological Indicators 28:54-78. http://dx.doi.org/10.1016/j.ecolind.2012.09.006

Kaplowitz, M. D., and J. P. Hoehn. 2001. Do focus groups and individual interviews reveal the same information for natural resource valuation? Ecological Economics 36(2):237-247. http:// dx.doi.org/10.1016/S0921-8009(00)00226-3

Kareiva, P., S. Watts, R. McDonald, and T. Boucher. 2007. Domesticated nature: shaping landscapes and ecosystems for human welfare. Science 316(5833):1866-1869. http://dx.doi. org/10.1126/science. 1140170

Karrasch, L., T. Klenke, and J. Woltjer. 2014. Linking the ecosystem services approach to social preferences and needs in integrated coastal land use management - a planning approach. Land Use Policy 38:522-532. http://dx.doi.org/10.1016/j. landusepol.2013.12.010

Kok, K. 2009. The potential of fuzzy cognitive maps for semiquantitative scenario development, with an example from Brazil. Global Environmental Change 19(1):122-133. http://dx.doi. org/10.1016/j.gloenvcha.2008.08.003

Kremen, C. 2005. Managing ecosystem services: what do we need to know about their ecology? Ecology letters 8(5):468-479. http:// dx.doi.org/10.1111/j.1461-0248.2005.00751.x 
Landuyt, D., S. Broekx, R. D'hondt, G. Engelen, J. Aertsens, and P. L. M. Goethals. 2013. A review of Bayesian belief networks in ecosystem service modelling. Environmental Modelling and Software 46:1-11. http://dx.doi.org/10.1016/j.envsoft.2013.03.011

Lamarque, P., P. Meyfroidt, B. Nettier, and S. Lavorel. 2014. How ecosystem services knowledge and values influence farmers' decision-making. PloS ONE 9(9):e107572. http://dx.doi. org/10.1371/journal.pone.0107572

Lamarque, P., U. Tappeiner, C. Turner, M. Steinbacher, R. D. Bardgett, U. Szukics, M. Schermer, and S. Lavorel. 2011. Stakeholder perceptions of grassland ecosystem services in relation to knowledge on soil fertility and biodiversity. Regional Environmental Change 11(4):791-804. http://dx.doi.org/10.1007/ s10113-011-0214-0

Lewan, L., and T. Söderqvist. 2002. Knowledge and recognition of ecosystem services among the general public in a drainage basin in Scania, Southern Sweden. Ecological Economics 42:459-467. http://dx.doi.org/10.1016/S0921-8009(02)00127-1

Luck, G. W., K. M. A. Chan, U. Eser, E. Gómez-Baggethun, B. Matzdorf, B. Norton, and M. B. Potschin. 2012. Ethical considerations in on-ground applications of the ecosystem services concept. BioScience 62(12):1020-1029. http://dx.doi. org/10.1525/bio.2012.62.12.4

Lugnot, M., and G. Martin. 2013. Biodiversity provides ecosystem services: scientific results versus stakeholders' knowledge. Regional Environmental Change 13(6):1145-1155. http://dx.doi.org/10.1007/s10113-013-0426-6

Martín-López, B., E. Gómez-Baggethun, M. García-Llorente, and C. Montes. 2014. Trade-offs across value-domains in ecosystem services assessment. Ecological Indicators 37:220-228. http://dx.doi.org/10.1016/j.ecolind.2013.03.003

Menzel, S., and M. Buchecker. 2013. Does participatory planning foster the transformation toward more adaptive social-ecological systems? Ecology and Society 18(1):13. http://dx.doi.org/10.5751/ ES-05154-180113

Millennium Ecosystem Assessment (MEA). 2005. Living beyond our means: natural assets and human well-being: statement from the board. Millennium Ecosystem Assessment, Washington, D. C., USA. [online] URL: http://www.millenniumassessment.org/ documents/document.429.aspx.pdf

Moreno, J., I. Palomo, J. Escalera, B. Martín-López, and C. Montes. 2014. Incorporating ecosystem services into ecosystembased management to deal with complexity: a participative mental model approach. Landscape Ecology 29(8):1407-1421. http://dx.doi.org/10.1007/s10980-014-0053-8

Mouchet, M. A., P. Lamarque, B. Martín-López, E. Crouzat, P. Gos, C. Byczek, and S. Lavorel. 2014. An interdisciplinary methodological guide for quantifying associations between ecosystem services. Global Environmental Change 28:298-308. http://dx.doi.org/10.1016/j.gloenvcha.2014.07.012

Palomo, I., M. R. Felipe-Lucía, E. M. Bennet, B. Martín-López, and U. Pascual. 2016. Disentangling the pathways and effects of ecosystem service co-production. Advances in Ecological Research 54:245-283 http://dx.doi.org/10.1016/bs.aecr.2015.09.003
Palomo, I., B. Martín-López, M. Potschin, R. Haines-Young, and C. Montes. 2013. National parks, buffer zones and surrounding lands: mapping ecosystem service flows. Ecosystem Services 4:104-116. http://dx.doi.org/10.1016/j.ecoser.2012.09.001

Raudsepp-Hearne, C., G. D. Peterson, and E. M. Bennett. 2010. Ecosystem service bundles for analyzing tradeoffs in diverse landscapes. Proceedings of the National Academy of Sciences 107 (11):5242-5247. http://dx.doi.org/10.1073/pnas.0907284107

Reyers, B., R. Biggs, G. S. Cumming, T. Elmqvist, A. P. Hejnowicz, and S. Polasky. 2013. Getting the measure of ecosystem services: a social-ecological approach. Frontiers in Ecology and the Environment 11(5):268-273. http://dx.doi.org/10.1890/120144

Rives, F., M. Antona, and S. Aubert. 2012. Social-ecological functions and vulnerability framework to analyze forest policy reforms. Ecology and Society 17(4):21. http://dx.doi.org/10.5751/ es-05182-170421

Rodríguez, J. P., T. D. Beard, Jr., E. M. Bennett, G. S. Cumming, S. J. Cork, J. Agard, A. P. Dobson, and G. D. Peterson. 2006. Trade-offs across space, time, and ecosystem services. Ecology And Society 11(1):28. [online] URL: http://www.ecologyandsociety. org/vol11/iss 1/art28/

Schneiders, A., T. Van Daele, W. Van Landuyt, and W. Van Reeth. 2012. Biodiversity and ecosystem services: complementary approaches for ecosystem management? Ecological Indicators 21:123-133. http://dx.doi.org/10.1016/j.ecolind.2011.06.021

Schröter, M., D. N. Barton, R. P. Remme, and L. Hein. 2014. Accounting for capacity and flow of ecosystem services: a conceptual model and a case study for Telemark, Norway. Ecological Indicators 36:539-551. http://dx.doi.org/10.1016/j. ecolind.2013.09.018

Schulp, C. J. E., S. Lautenbach, and P. H. Verburg. 2014. Quantifying and mapping ecosystem services: demand and supply of pollination in the European Union. Ecological Indicators 36:131-141. http://dx.doi.org/10.1016/j.ecolind.2013.07.014

Spangenberg, J. H., C. Görg, D. T. Truong, V. Tekken, J. V. Bustamante, and J. Settele. 2014. Provision of ecosystem services is determined by human agency, not ecosystem functions. Four case studies. International Journal of Biodiversity Science, Ecosystem Services and Management 10(1):40-53. http://dx.doi. org/10.1080/21513732.2014.884166

Sutherland, W. J., T. A. Gardner, L. J. Haider, and L. V. Dicks. 2013. How can local and traditional knowledge be effectively incorporated into international assessments? Oryx 48:1-2. http:// dx.doi.org/10.1017/S0030605313001543

Tappeiner, U., A. Borsdorf, and E. Tasser. 2008. Mapping the Alps. Spektrum A. Die Deutsche Bibliothek, Heidelberg, Germany.

Van der Biest, K., R. D’Hondt, S. Jacobs, D. Landuyt, J. Staes, P. Goethals, and P. Meire. 2014. EBI: an index for delivery of ecosystem service bundles. Ecological Indicators 37:252-265. http://dx.doi.org/10.1016/j.ecolind.2013.04.006

Villamagna, A. M., P. L. Angermeier, and E. M. Bennett. 2013. Capacity, pressure, demand, and flow: a conceptual framework for analyzing ecosystem service provision and delivery. Ecological Complexity 15:114-121. http://dx.doi.org/10.1016/j.ecocom.2013.07.004 
Willemen, L., A. Veldkamp, P. H. Verburg, L. Hein, and R. Leemans, 2012. A multi-scale modelling approach for analysing landscape service dynamics. Journal of Environmental Management 100:86-95. http://dx.doi.org/10.1016/j.jenvman.2012.01.022

Wolff, S., C. J. E. Schulp, and P. H. Verburg. 2015. Mapping ecosystem services demand: a review of current research and future perspectives. Ecological Indicators 55:159-171. http://dx. doi.org/10.1016/j.ecolind.2015.03.016

Zulian, G., J. Maes, and M. L. Paracchini. 2013. Linking land cover data and crop yields for mapping and assessment of pollination services in Europe. Land 2(3):472-492. http://dx.doi. org/10.3390/land 2030472 
Appendix1.

Fig.A1.1: Profiles of stakeholders consulted during the different consultation steps of the Influence Network Framework exercise: gender (A.), type of organisation (B.) and main type of expertise (C.). Envirn. Mngt: Environmental Management, Nature cons.: Nature conservation.

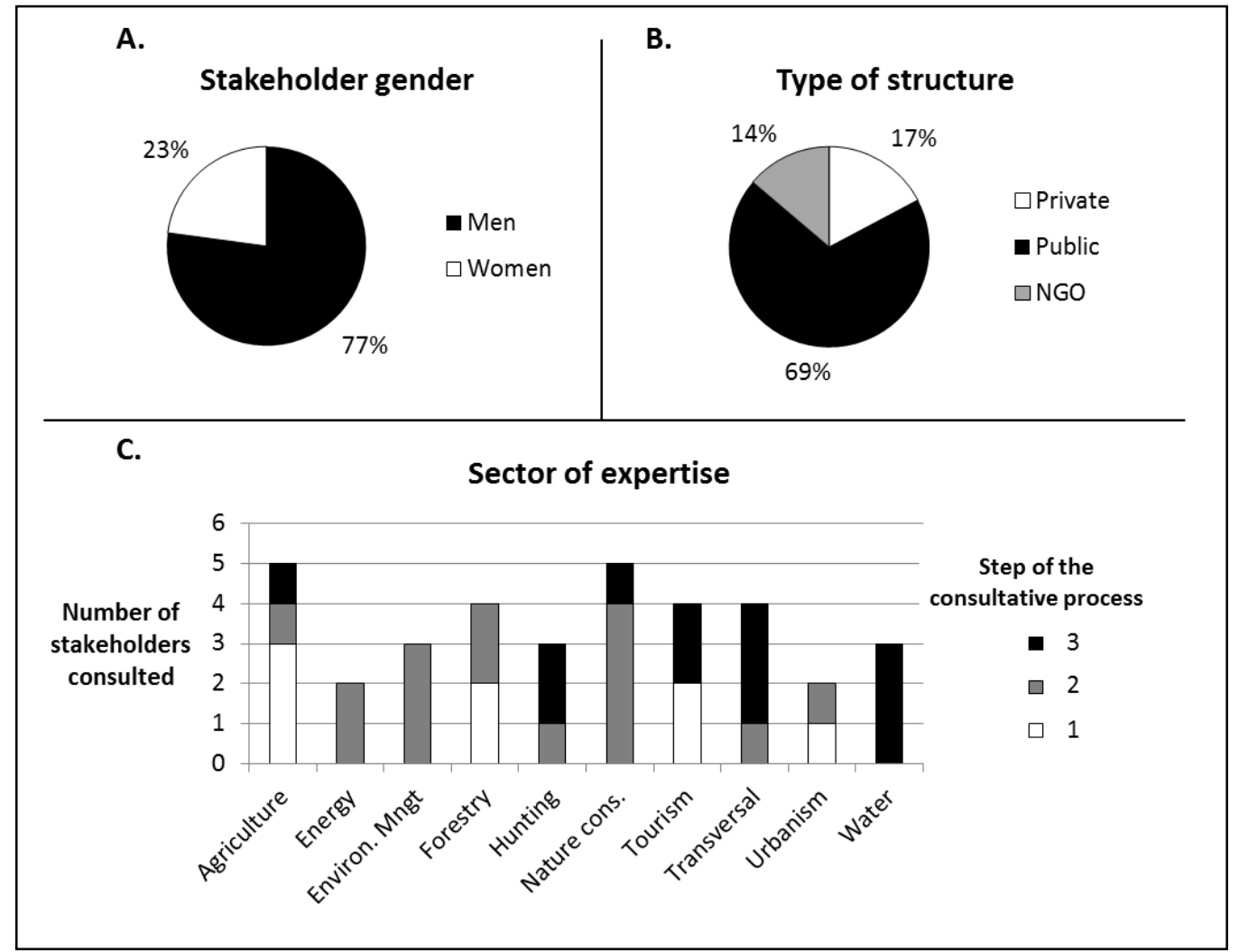


Appendix 2.

Table A2.1: Influence matrix showing all pairwise influences mentioned by stakeholders during the consultative process. 


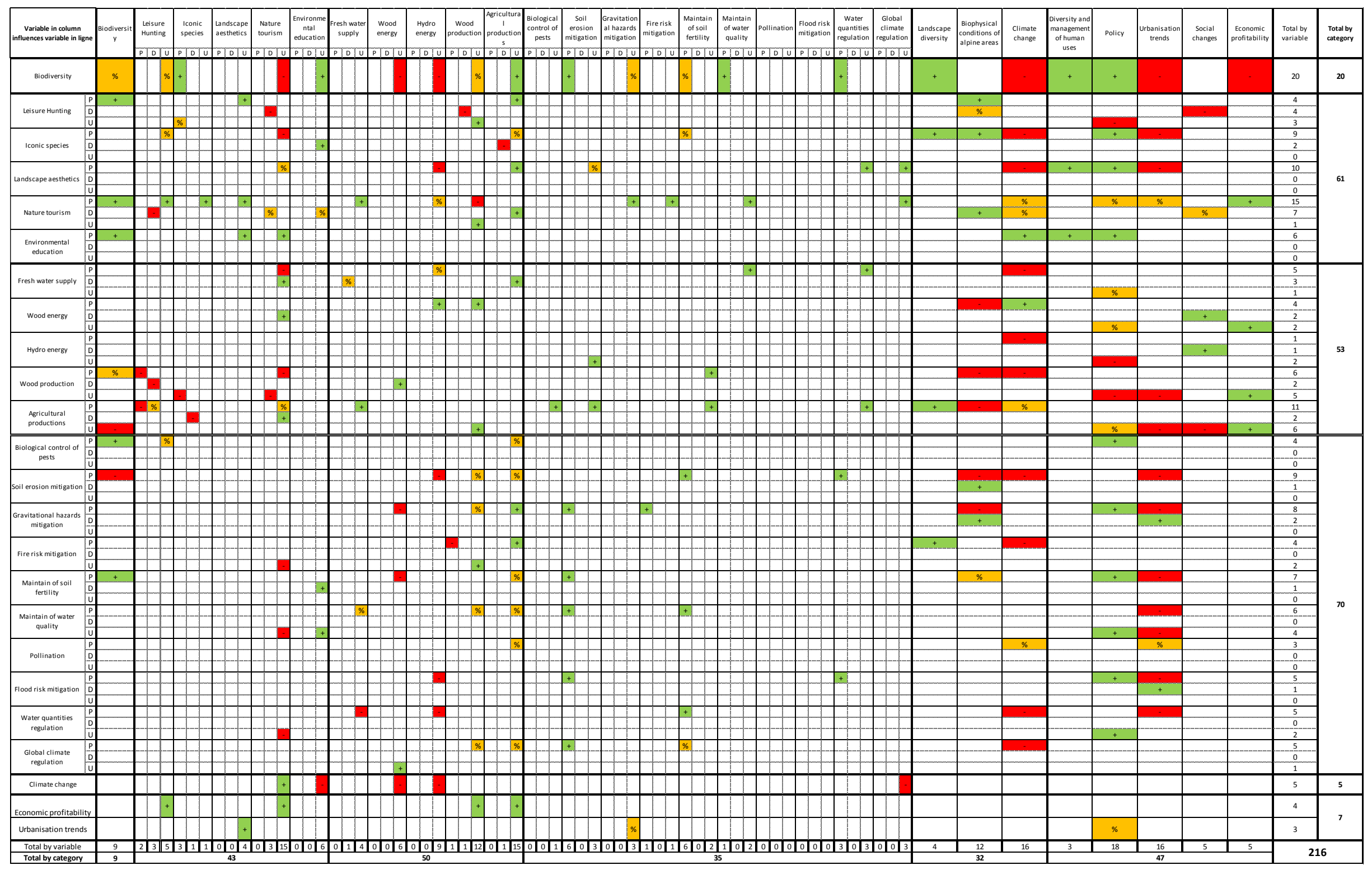


Appendix 3.

Table A3.1: Total number of influence relationships emitted by category in column and received by category in line, extracted from the global influence matrix (Appendix 2).

\begin{tabular}{|l|r|r|r|r|r|r|r|}
\hline & Biodiversity & Cultural ES & $\begin{array}{c}\text { Provisioning } \\
\text { ES }\end{array}$ & $\begin{array}{c}\text { Regulating } \\
\text { ES }\end{array}$ & $\begin{array}{c}\text { Ecological } \\
\text { variable }\end{array}$ & $\begin{array}{c}\text { Social } \\
\text { variable }\end{array}$ & TOTAL \\
\hline Biodiversity & 1 & 4 & 4 & 5 & 2 & 4 & $\mathbf{2 0}$ \\
\hline Cultural ES & 3 & 15 & 12 & 8 & 10 & 13 & $\mathbf{6 1}$ \\
\hline Provisioning ES & 2 & 13 & 8 & 8 & 9 & 13 & $\mathbf{5 3}$ \\
\hline Regulating ES & 3 & 6 & 22 & 12 & 11 & 16 & $\mathbf{7 0}$ \\
\hline Ecological variable & 0 & 2 & 2 & 1 & 0 & 0 & $\mathbf{5}$ \\
\hline Social variable & 0 & 3 & 2 & 1 & 0 & 1 & $\mathbf{7}$ \\
\hline TOTAL & $\mathbf{9}$ & $\mathbf{4 3}$ & $\mathbf{5 0}$ & $\mathbf{3 5}$ & $\mathbf{3 2}$ & $\mathbf{4 7}$ & $\mathbf{2 1 6}$ \\
\hline
\end{tabular}

Table A3.2: Pairwise influence ratio by category - Number of influences emitted by the category in column toward the category in line divided by the number of influences emitted by the category in line toward the category in column. The ratio is higher than 1 when the category in column emit more influences toward the category in line than the opposite; conversely, the ratio is lower than 1 when the category in column emit less influences to the category in line than the opposite. 


\begin{tabular}{|l|r|r|r|r|r|}
\cline { 2 - 6 } \multicolumn{1}{c|}{} & Biodiversity & Cultural ES & $\begin{array}{c}\text { Provisioning } \\
\text { ES }\end{array}$ & $\begin{array}{c}\text { Regulating } \\
\text { ES }\end{array}$ & $\begin{array}{c}\text { Ecological } \\
\text { variable }\end{array}$ \\
\hline Cultural ES & 0,75 & & & & \\
\hline Provisioning ES & 0,50 & 1,08 & & & \\
\hline Regulating ES & 0,60 & 0,75 & 2,75 & & \\
\hline Ecological variable & 0,00 & 0,20 & 0,22 & 0,09 & \\
\hline Social variable & 0,00 & 0,23 & 0,15 & 0,06 & \\
\hline
\end{tabular}

